\title{
A Clinical Study of Acute Hydrogen Cyanamide Toxicity in the Period between 2006-2009 in the Poison Control Center, Ain Shams University
}

\author{
Hany A. Gamaluddin, Suzan M. Mahmmoud, Mona E. Mosa, Heba M. Halawa, \\ and Eman A. Khalifa1
}

\footnotetext{
${ }^{1}$ Department of Forensic Medicine and Clinical Toxicology, Faculty of Medicine, Ain Shams University. Cairo, Egypt. All rights reserved.
}

\begin{abstract}
Hydrogen cyanamide is an active ingredient of Dormex ${ }^{\circledR}$ used as a plant growth regulator. Reports of the acute toxic effects of hydrogen cyanamide are limited. The emerging problem of Dormex toxicity approximately started in Egypt since 1997 and led to many deaths. Therefore, the aim of this study was to illustrate acute toxic effects of hydrogen cyanamide. Subjects and Method: The study was carried out on hydrogen cyanamide intoxicated cases presented to the poison control center (PCC), Ain Shams University Hospitals in the period between January 2006 and December 2009. Symptoms, signs, laboratory investigations, and complications were recorded at the time of presentation. The study was conducted on 12 patients with acute Dormex toxicity in addition to 10 healthy individuals serving as control. Conclusion: Dormex is highly toxic and may cause serious poisoning with acute toxic effects on central nervous system, respiratory and cardiovascular systems, liver, kidney, and hematological system. So awareness of this complications and early aggressive treatment are recommended to reduce mortality.
\end{abstract}

\section{Introduction}

$\mathrm{C}$ yanamide is widely used as a plant growth regulator and has many uses in chemical industry. Hydrogen cyanamide was first registered for use in 1984 (Bradbury, 2007). However, the toxicity of hydrogen cyanamide and relatively its high price limit its market acceptance and place it on the European Red List of agricultural chemicals. Its use is restricted in some countries, including the USA. A pesticide product containing hydrogen cyanamide was first introduced in Italy in 2000 (OSHA, 2001).

Cyanamide is used as antabuse for alcoholics. The mechanism of cyanamide to discourage alcohol consumption is inhibition of aldhyde dehydrogenase resulting in the accumulation of acetaldehyde (Ajima et al., 1997). It is sold either as an aqueous solution or as slow-release tablets, with various trade-names, such as Abstem, Colme, and DORMEX.

Hydrogen cyanamide (DORMEX) is a blue odorless liquid. Safety guidelines consider the product as severely toxic. Cyanamide is rapidly absorbed from the gastrointestinal tract with variable bioavailability (45-80\%) depending on the dose, while dermal absorption is slower (Schep et al., 2009).
Despite its extensive use in agriculture, little is known about the effects of exposure to hydrogen cyanamide. Diagnostic test of hydrogen cyanamide poisoning is lacking thus, medical evaluation should focus on identifying the toxic effects of cyanamide.

Hydrogen cyanamide is highly toxic and may be fatal if swallowed, inhaled, or absorbed through the skin. Toxic effects from contact include severe irritation and ulceration of skin, eyes, gastrointestinal and respiratory tracts. Systemic poisoning by hydrogen cyanamide may cause parasympathetic overactivity. In large doses circulatory depression and coma are possible (MSDS, 2005).

\section{Subjects and Methods}

This study was conducted on 12 patients with acute Dormex toxicity admitted to Poison Control Centre (PCC), Ain Shams University Hospitals in the period from January 2006 till December 2009, in addition to 10 healthy control subjects.

Diagnosis of poisoning with hydrogen cyanamide was based on history of exposure to 
hydrogen cyanamide, Dormex ${ }^{\circledR}$, and interpretation of signs and symptoms. Patients under this study had no history of previous neurological, cardiovascular, respiratory, hepatic, renal, or hematological troubles. Written consent from all patients or their relatives was taken. Illness severity was categorized for all cases according to Settimi et al., (2005). Mild to moderate severity illness consists of minimally bothersome health effects that generally resolve rapidly, or injury consists of non--life-threatening health effects. Severe illness consists of life-threatening health effects or those that result in substantial residual disability or disfigurement. Subjects under study were divided into 3 groups:

- Group A: control group which consist of 10 healthy adult individuals.

- Group B: six patients with mild to moderate intoxication by Dormex.

- Group C: six patients severely intoxicated by Dormex.

In each patient symptoms and signs were recorded at the time of presentation. Laboratory investigations were done and included: liver enzymes (aspartate aminotransferase (AST) and alanine aminotransferase (ALT)), prothrombin time (PT), total and direct bilirubin, serum creatinine, $\mathrm{CPK}$, arterial blood gases (ABG), complete blood count (CBC) and pseudocholinesterase activity. Chest x-ray was also done for every case. Photographs of skin burns were also taken. An observational sheet was designed and was fed by patients' data on admission and during the hospital stay and outcome of cases were also recorded.

\section{Statistical analysis}

The obtained results were recorded and organized for statistical analysis using SPSS (Statistical Package for the Social Science) version 13 software. All quantitative data were expressed as mean $\pm \mathrm{SD}$. The numerical description of data was done using descriptive statistics. Quantitative variables were compared using ANOVA test. In all tests the probability ( $\mathrm{P}$ ) was used, if $\mathrm{P}<0.05$ the comparison was significant, if $\mathrm{P}>0.05$ the comparison was nonsignificant while if $\mathrm{P}<0.001$ the comparison was considered highly significant.

\section{Results}

The number and percentages of recorded signs and symptoms on admission were shown in table (1). The commonest clinical manifestations were tachypnea, coma miosis, vomiting, and bradycardia. In severe cases shock, pulmonary edema and respiratory failure were also found.

Regarding the biochemical parameters, table (2) showed that, there was highly significant rise of AST and ALT in group B (moderate group) and group C (severe group) when compared with group A (control group), and also highly significant difference was noted between moderate and severe group of patients. Table (2) also showed highly significant elevation of PT, total and direct bilirubin, serum creatinine, and CPK level in group $\mathrm{C}$ (severe group) when compared with group A and B (control and moderate group).

Regarding arterial blood gases analysis, table 3 showed a significant decrease in $\mathrm{pH}$ and serum $\mathrm{HCO}_{3}$ in group $\mathrm{C}$ (severe group) when compared with group $\mathrm{A}$ and $\mathrm{B}$ (control and moderate group).

Table (4) showed a highly significant increase in WBCs count in group B and C (moderate and severe groups) when compared with group A (control group), but non-significant difference was noted between moderate and severe groups. Table (4) also showed that, there was highly significant decrease in platelets in group B (moderate group) and group C (severe group) when compared with group A (control group).

Table (5) showed that there was nonsignificant difference between the three studied groups as regard pseudocholinesterase level.

Table (6) showed that in the 12 patients with acute Dormex intoxication the respiratory system manifestations were tachypnea in almost all cases $11(91.7 \%)$, bradypnea in only one patient $(8.3 \%)$.

The most common respiratory complication among these patients was respiratory failure type 1 reported in 5 patients $(41.7 \%)$, non cardiogenic pulmonary edema was also reported in 4 patients (33.3\%), as proved by chest X-ray (figure 2).

Regarding treatment of acute Dormex toxicity, no antidote but symptomatic and resuscitative treatment was used. In case of ingestion dilution with water or milk was done. Activated charcoal was administrated in mild ingestion cases .In severe hypotension and shocked cases anti-shock measures were used. In cases of skin exposure corticoid containing preparations were used. Patients with Dormex exposure were kept under medical supervision for at least 24 hours.

Regarding the survival pattern in the 12patients with acute Dormex poisoning, table (7) demonstrated that mortality occurred in 4 cases $(33.3$ $\%)$. The main cause of mortality was multisystem organ failure in 3 cases ( $75 \%$ of deaths), while shock 
was the cause of death in one patient, (25\% of deaths).

Table (1): Clinical signs and symptoms of the 12 patients with acute Dormex toxicity.

\begin{tabular}{|l|c|}
\hline Sign or symptom & Number of patients \\
\hline Tachypnea & $11(91.7 \%)$ \\
\hline Coma & $10(83.3 \%)$ \\
\hline Miosis & $8(66.7 \%)$ \\
\hline Bradycardia & $8(66.7 \%)$ \\
\hline Hallucination & $5(41.7 \%)$ \\
\hline Respiratory failure & $5(41.7 \%)$ \\
\hline Pulmonary edema & $4(33.3 \%)$ \\
\hline Vomiting & $4(33.3 \%)$ \\
\hline Hypotension & $3(25 \%)$ \\
\hline Shock & $3(25 \%)$ \\
\hline Burn & $2(16.7 \%)$ \\
\hline Hematemesis & $2(16.7 \%)$ \\
\hline Jaundice & $2(16.7 \%)$ \\
\hline
\end{tabular}

Table (2): ANOVA one-way statistical analysis of biochemical parameters (AST, ALT, PT, total and direct bilirubin, serum creatinine and CPK) in the studied groups, group A (control group n=10), group B (moderate group $n=6$ ) and group $C($ severe group $n=6)$.

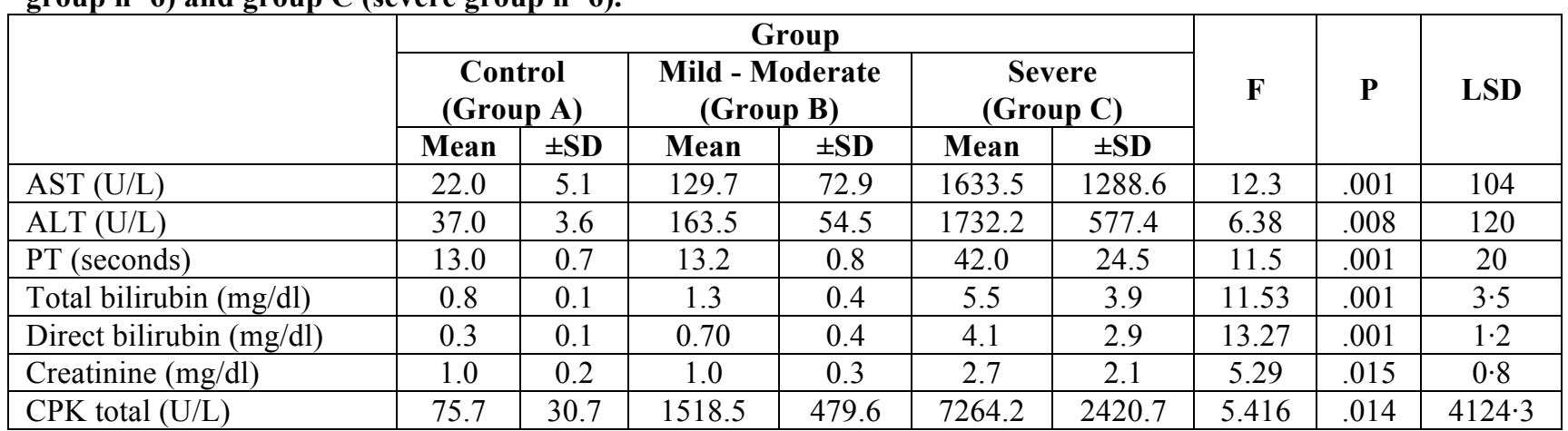

$S D=$ Standard Deviation. $F=$ variance ratio calculated by ANOVA one-way statistical analysis.

$P>0.05$ non significant, $P<0.05$ significant, $P<0.001$ highly significant, $L S D=$ Least Significant Difference.

Table (3): ANOVA one-way statistical analysis of arterial (pH, PaO2, $\mathrm{PaCO}, \mathrm{SaO2}$ and $\mathrm{HCO3}$ ) in the studied groups, group A (control group $n=10)$, group B (moderate group $n=6)$ and group C (severe group $n=6)$.

\begin{tabular}{|c|c|c|c|c|c|c|c|c|c|}
\hline & \multicolumn{6}{|c|}{ Group } & \multirow{3}{*}{$\mathbf{F}$} & \multirow{3}{*}{$\mathbf{P}$} & \multirow{3}{*}{ LSD } \\
\hline & \multicolumn{2}{|c|}{$\begin{array}{c}\text { Control } \\
(\text { Group A) }\end{array}$} & \multicolumn{2}{|c|}{$\begin{array}{l}\text { Mild- moderate } \\
\text { (Group B) }\end{array}$} & \multicolumn{2}{|c|}{$\begin{array}{c}\text { Severe } \\
\text { (Group C) }\end{array}$} & & & \\
\hline & Mean & \pm SD & Mean & \pm SD & Mean & \pm SD & & & \\
\hline $\mathrm{PH}$ & 7.4 & .05 & 7.4 & 0.1 & 7.2 & 0.1 & 8.142 & .003 & $0 \cdot 1$ \\
\hline PO2 (mmHg) & 82.4 & 3.9 & 79.8 & 7.6 & 64.8 & 6.6 & 18.08 & .001 & $8 \cdot 2$ \\
\hline PCO2 (mmHg) & 39.5 & 6.0 & 34.5 & 8.3 & 31.0 & 6.3 & 3.11 & .068 & $\begin{array}{ll}---- \\
\end{array}$ \\
\hline $\mathrm{HCO} 3(\mathrm{mEq})$ & 22.9 & 2.2 & 19.8 & 4.2 & 14.7 & 4.5 & 10.19 & .001 & $4 \cdot 3$ \\
\hline $\mathrm{O} 2$ saturation $(\%)$ & 96.4 & 2.8 & 95.6 & 2.7 & 92.5 & 5.9 & 1.95 & .169 & ---- \\
\hline
\end{tabular}

Table (4): ANOVA one-way statistical analysis of blood picture (WBCs, RBCs, Hb and platelets) in the studied groups, group A (control group $n=10)$, group B (moderate group $n=6)$ and group $C(\operatorname{severe~group~} n=6)$.

\begin{tabular}{|c|c|c|c|c|c|c|c|c|c|}
\hline & \multicolumn{6}{|c|}{ Group } & \multirow{3}{*}{$\mathbf{F}$} & \multirow{3}{*}{$\mathbf{P}$} & \multirow{3}{*}{ LSD } \\
\hline & \multicolumn{2}{|c|}{$\begin{array}{c}\text { Control } \\
(\text { Group A) }\end{array}$} & \multicolumn{2}{|c|}{$\begin{array}{l}\text { Mild to Moderate } \\
\text { (Group B) }\end{array}$} & \multicolumn{2}{|c|}{$\begin{array}{c}\text { Severe } \\
\text { (Group C) }\end{array}$} & & & \\
\hline & Mean & \pm SD & Mean & \pm SD & Mean & \pm SD & & & \\
\hline WBCs $/ \mathrm{cmm}$ & 6.5 & 1.6 & 12.4 & 2.5 & 14.6 & 8.6 & 6.307 & .008 & $3 \cdot 4$ \\
\hline RBCs /cmm & 4.8 & 0.8 & 5.1 & 0.6 & 5.6 & 0.7 & 2.289 & .129 & \\
\hline $\mathrm{Hb}(\mathrm{g} / \mathrm{dl})$ & 13.6 & 1.5 & 14.6 & 2.1 & 15.5 & 2.0 & 2.191 & .139 & \\
\hline Platelets/cmm & 327.0 & 30.8 & 127.3 & 52.8 & 110.0 & 36.1 & 77.824 & .001 & $80 \cdot 6$ \\
\hline
\end{tabular}

$S D=$ Standard Deviation. $F=$ variance ratio calculated by ANOVA one-way statistical analysis. 
$P>0.05$ non significant, $P<0.05$ significant, $P<0.001$ highly significant, $L S D=$ Least Significant Difference.

Table (5): ANOVA one-way statistical analysis of pseudocholinestrase (PChE) level in the studied groups, group A (control group $n=10)$, group $B($ moderate group $n=6)$ and group $C$ (severe group $n=6)$.

\begin{tabular}{|l|c|c|c|c|c|}
\hline & $\begin{array}{c}\text { Group A } \\
\text { (control cases, } \mathbf{n = 1 0}) \\
\text { mean } \pm \text { SD }\end{array}$ & $\begin{array}{c}\text { Group B } \\
\text { (mild-moderate cases, } \mathbf{n = 6}) \\
\text { mean } \pm \text { SD }\end{array}$ & $\begin{array}{c}\text { Group C } \\
\text { (severe cases, } \mathbf{n = 6}) \\
\text { mean } \pm \text { SD }\end{array}$ & $\mathbf{F}$ & $\mathbf{P}$ \\
\hline $\mathrm{PChE}$ level $(\mathrm{U} / \mathrm{l})$ & $2617.9 \pm 506.32$ & $2489.7 \pm 498.8$ & $2537.4 \pm 475.7$ & 0.14 & 0.874 \\
\hline
\end{tabular}

$S D=$ Standard Deviation. $F=$ variance ratio calculated by ANOVA one-way statistical analysis. $P>0.05$ non significant

Table (6): Percentage of the respiratory manifestations and chest-X ray (CXR) finding in the 12 patients with acute Dormex poisoning.

\begin{tabular}{|l|l|c|c|}
\hline \multicolumn{2}{|c|}{ Respiratory manifestation } & Number & Percent (\%) \\
\hline \multirow{2}{*}{ Respiratory Rate } & Tachypnea & 11 & $91.7 \%$ \\
\cline { 2 - 4 } & Bradypnea & 1 & $8.3 \%$ \\
\hline Respiratory failure & Respiratory Failure type 1 & 5 & $41.7 \%$ \\
\hline \multirow{2}{*}{ CXR } & Normal & 8 & $66.7 \%$ \\
\cline { 2 - 4 } & Pulmonary edema & 4 & $33.3 \%$ \\
\hline
\end{tabular}

Table (7): Survival pattern among the12 patients with acute Dormex poisoning and causes of death.

\begin{tabular}{|c|c|c|c|}
\hline Outcome & Survival & \multicolumn{3}{|c|}{ Death } \\
\hline Number & 8 & \multicolumn{2}{|c|}{4} \\
\hline Cause of death & & Multisystem organ failure (3) & Shock (1) \\
\hline
\end{tabular}

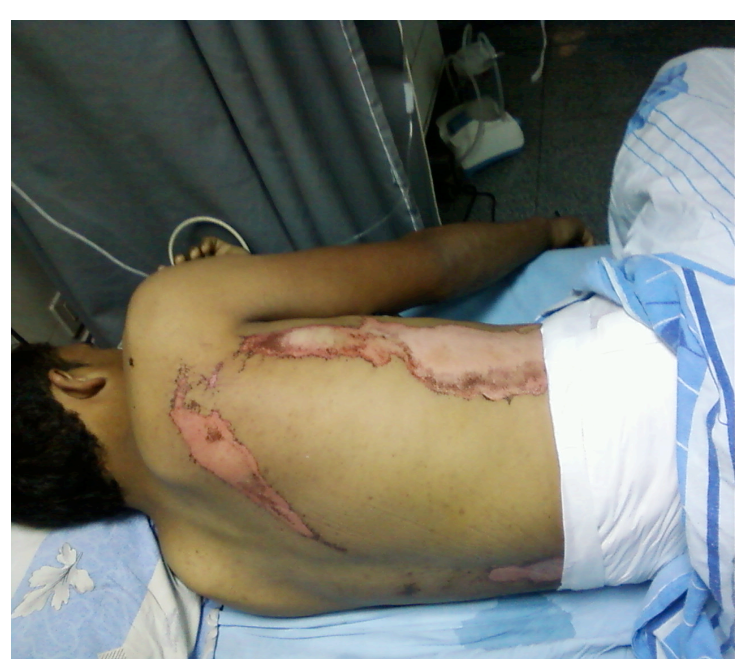

Figure (1A)

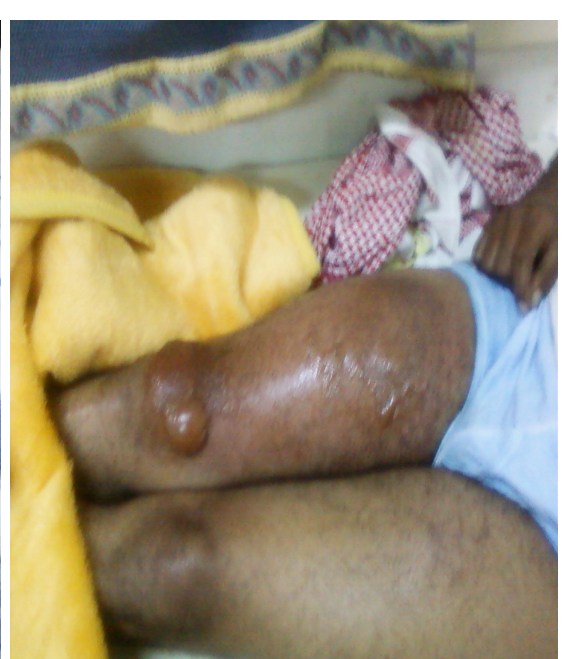

Figure (1B)

Figure (1A): chemical burn in the back of patient with acute dermal exposure to Dormex. Figure (1B): Bullae and edema in the lower limbs of patient with acute dermal exposure to Dormex.

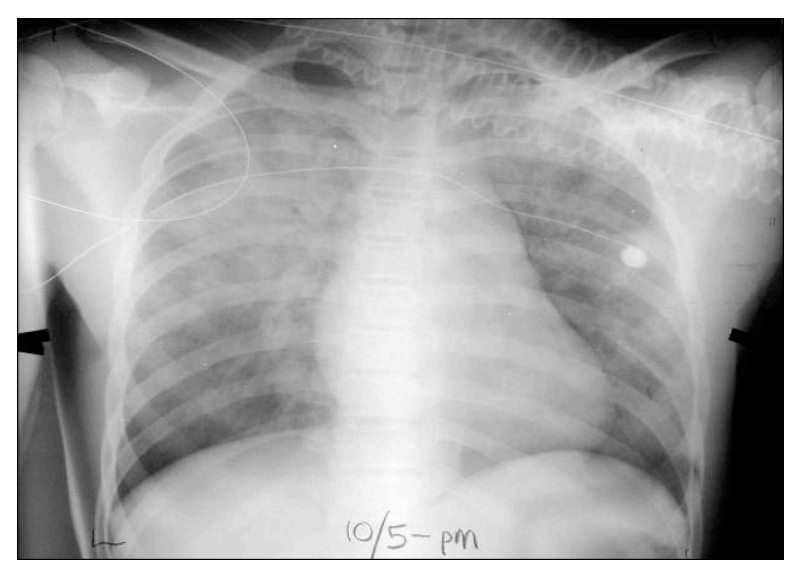

Figure (2): Chest x-ray showing non-cardiogenic pulmonary edema (fluffy cotton infiltrates in both lung fileds 


\section{with normal heart size)}

\section{Discussion}

Hydrogen cyanamide, the active ingredient of Dormex ${ }^{\circledR}$ is a plant growth regulator widely used as fertilizer to stimulate more uniform bud-break. Environmental Protection Agency (EPA) places both the active ingredient (hydrogen cyanamide) and the product (Dormex ${ }^{\circledR}$ ), which contains $50 \%$ hydrogen cyanamide, into the highest toxicity category (toxicity category I) because of its corrosive effects on the skin and eyes (EPA, 2003).

In the present study the commonest clinical manifestations were miosis, vomiting, and bradycardia, these coincide with the manifestations recorded by Schep et al., (2009) and Sheshadri et al., (2011). Miosis, bradycardia, and vomiting were observed in large proportion of patients which could be explained by parasympathetic overactivity as stated by Grant (1986).

Hypotension and shock were frequent signs in the present study reported in $50 \%$ of patients. This could be attributed to the vasodilator effect of nitroxyl radical that resulted from oxidation of cyanamide by the catalase enzyme as explained by Shahidullah et al., (2002).

In the present study local manifestations due to direct contact with Dormex were in the form of caustic burn of the skin and hematemesis when ingested. This was also explained by Colom et al., (1999) who stated that direct contact to cyanamide causes severe irritation and ulceration of the skin, gastrointestinal respiratory tract and eyes.

The exact mechanism of action of hydrogen cyanamide has not been established. De Zwart et al., (1999) mentioned that cyanamide inhibits catalase, an enzyme whose normal function is to remove excess hydrogen peroxides. The inhibition of this process resulting in oxidative damage.

In the present study highly significant increase in the liver enzymes, AST and ALT, was noticed in moderate and severe groups of patients. Drug induced liver injury that results in cytolysis and necrosis causes the liberation of various hepatic enzymes. Elevated aminotransferases (AST and ALT) indicate hepatocellular damage (Krefetz, 2000).

There was a significant prolongation in PT in the severe group of patients only, thus prolonged PT was correlated with poor prognosis. This could be explained as PT is commonly increased in liver disease because the liver is unable to manufacture adequate amounts of clotting factors or due to disruption of bile flow resulting from inadequate absorption of vitamin $\mathrm{K}$ from the intestine. Thus marked prolongation of the PT indicates severe diffuse liver disease and poor prognosis (Fody, 2000)

In the current study highly significant increase in total and direct bilirubin was noticed in the severe group of patients. This could be explained by obstruction of bile flow. Conjugated or direct bilirubin is secreted from the hepatic cells into bile canaliculi and then passes into larger bile ducts and then secreted into the intestine (Fody, 2000).

Zimmeman, (1999) reported three cases of acute cholestasis due to cyanamide toxicity and explained this by drug induced cholestasis.

In the present study there was a significant elevation of serum creatinine only in severe cyanamide cases. This could be attributed to the direct toxic effect of Dormex or due to severe hypotension and shock (Xie et al., 2010)

Creatinine phosphokinase (CPK) significantly increased only in severe cyanamide cases in the current study. Elevation of CPK is an indication of muscle damage. It is therefore indicative of injury, rhabdomyolysis, myocardial

infarction, myositis and myocarditis and it also increase in acute renal failure (Schlattner et al., 2006)

In the present study arterial blood gases (ABG) revealed highly significant reduction in $\mathrm{PH}$, $\mathrm{PO} 2$ and $\mathrm{HCO} 3$ level in severe group of patients. The reduction in $\mathrm{PO} 2$ indicates respiratory failure that occurred in the severe group of patients.

The reduction in $\mathrm{PH}$ and $\mathrm{HCO} 3$ in the current study indicating metabolic acidosis which could be explained by cyanamide action as cellular poison inhibiting cellular respiration (Manoilov et al., 1996), so cells depend on anaerobic metabolism resulting in more lactic acid production. Lactic acidosis may also due to shock resulting in an inadequate blood and oxygen delivery to tissues.

In the present study blood picture showed significant increase of WBCs count but the platelets were significantly decreased. However no significant change was noticed regarding RBCs count or hemoglobin concentration.

The high WBCs count could be explained by the inflammatory response of the body and could also explained by Mitani et al., (2005) who reported a case with marked leukocytosis and eosinophilia associated with generalized eruption after cyanamide intake.

The hypersensitivity reaction to cyanamide was confirmed as serum antibodies to cyanamide were detected in $72 \%$ of 60 workers who had been in contact with cyanamide in a study done by Gloxhuber et al., (1989).

Low platelets count could be due to decreased production of platelets as a result of decreased thrombopoietin due to underlying liver and renal failure. Thrombopoietin is a glycoprotein hormone produced mainly by the liver and the kidney that regulates the production of platelets by the bone marrow (Cheung et al., 2005).

In the present study pseudocholinesterase was normal in all patients. Pseudocholinesterase level was done to exclude organophosphate toxicity as Dormex was classified in Italy 2001 as pesticide related illness and also due to the mimic picture of parasympathetic overactivity between the two compounds (Davanzo et al., 2001). 
In the present study tachypnea was found in almost all patients $(91.7 \%)$, this was in accordance with Sheshadri et al., (2011) who reported that ingestion of hydrogen cyanamide may produce rapid breathing. Tachypnea could be due to metabolic acidosis, in which breathing is first rapid and shallow, but as acidosis worsens, breathing gradually becomes deep, labored and gasping (Robin et al., 2006).

Pulmonary edema was reported in severe cases in the current study. This result was also reported by MSDS (2005) who stated that pulmonary edema or pneumonitis may occur following cyanamide exposure due to injury to the lung parenchyma or vasculature.

Respiratory failure type I (hypoxia without hypercapnia) was found in 5 cases $(41.7 \%)$. This could be explained by underlying pulmonary edema which leads to impaired gas exchange (Ware and Matthay, 2005).

Advisable therapy of acute cyanamide exposure include rinsing with plenty of water for at least 15 minutes, removal of contaminated clothes and corticoid containing preparation in cases of dermal exposure. Removal to fresh air and oxygen if inhaled. In case of ingestion dilution with water or milk should be done according to emergency guidelines of manufacturer. If massive ingestion circulatory function should be monitored. Patient with cyanamide exposure must be kept under medical supervision for at least 24 hours (MSDS, 2005).

In the present study mortality was reported in 4 patients (33\% of patients), despite intensive symptomatic and resuscitative therapy. This was due to multisystem organ failure in 3 cases ( $75 \%$ of deaths), while shock was the cause of death in one patient $(25 \%$ of deaths).

\section{Conclusion}

Hydrogen cyanamide is a fertilizer with dramatic fatal outcome on acute severe exposure. It exerts its action by inhibition of catalase enzyme resulting in oxidative damage including hepatic, renal, and lung damage. Other systems as central nervous system, cardiovascular system, and hemopoeitic system are evidently affected. So awareness of this complications and early aggressive treatment are recommended to reduce mortality.

\section{References}

Ajima M, Usuki K, Igarashi A et al., (1997): Cyanamide-Induced granulocytopenia. Internal Medicine; 36: 640-42.

Bradbury S (2007): Hydrogen cyanamide (cyanamide) summary document registration review initial docket docket number EPA-HQ-OPP-20071014 www.regulations.gov

Cheung R, McAuley R, and Pollard J (2005): High mortality rate in patients with advanced liver disease independent of exposure to general anesthesia". Journal of Clinical Anesthesia 17 (3): 172-766.

Colom H, Prunonosa J, Peraire C et al., (1999): Absolute bioavailability and absorption profile of cyanamide in man. J Pharmacokinet Biopharm; 27(4):421-36.

Davanzo F, Faraoni L, Miceli G et al., (2001): Pesticide-related illnesses associated with the use of a plant growth regulator-Italy. MMWR Morb Mortal Wkly Rep; 50:845-47.

De Zwart L, Vermeulen P, Hermanns C et al., (1999): Urinary excretion of biomarkers for radical induced damage in rats treated with NDMA or diquat and effects of calcium carbimide coadministration. Chem. Biol.Interact; 117(2):151-72.

EPA (2003): Environmental Protection Agency. Information Statistics. Washington.EPA from a calcium cyanamide production plant. Zentralbl Arbeitsmed Arbeitsschutz Prophyl Ergonomie; 43: 254-58.

Fody EP (2000): Liver function.In:Clinical Chemistry Princeples,Procedures,Correlations,Bishop ML,Engelkirk JD and Fody EP,(eds), $4^{\text {th }}$ edition ,Lippincott Williams and Wilkins,pp:354-69.

Gloxhuber C, Wittman H, Bornemann W et al., (1989): Clinical examination of hypersensitization towards hydrogen cyanamide and calcium cyanamide in employees of the calcium cyanamide production plant of SKW Trostberg. Pesticide Registration Document Number 50660-049.

Grant WM (1986): Toxicology of the eye. 3rd ed. Springfield, Illinois: Charles C. Tomas Publisher, pp: 286.

Krefetz RG (2000): Enzymes. In :Clinical Chemistry Principles, Procedures, Correlations ,Bishop ML , Engelkirk JD and Fody EP,(eds), $4^{\text {th }}$ edition, Lippincott Willliams and Wilkins,pp:185-214.

Manoilov S, Sedykh N, Firsova V et al., (1996): Effect of the catalase inhibitor 3-amino-1,2,4-triazole on oxidation-phosphorylation coupling and the state of the mitochondrial adenosine system in the liver of albino rats. Bull Exp Biol Med; 121:576-78.

Mitani N, Itoh N, MizuAihara M et al., (2005): Druginduced hypersensitivity syndrome due to cyanamide associated with multiple reactivation of human herpesviruses $\mathrm{J}$ Med Virol.; 75(3):430-34.

MSDS (2005): Material Safety Data Sheet. Cyanamide MSDS available at: http://www.sciencelab.com/msds.

OSHA (2001): Occupational Safety and Health Administration. OSHA health guidelines. Safety and health topics: NIOSH/OSHA/DOE. Occupational safety and health guideline for cyanamide. Available at http://www.osha.gov/sltc/healthguidelines/cya namide/recognition.html.

Robin RD, Winn W, Myron J et al., (2006): Current Diagnosis and Treatment in Pediatrics (Current Pediatric Diagnosis and Treatment). McGraw-Hill Medical, .pp: 989. 
Schep L, Temple W and Beasley M (2009): The adverse effects of hydrogen cyanamide on human health: an evaluation of inquiries to the New Zealand National Poisons Centre. Clin Toxicol; 47(1):58-60.

Schlattner U, Tokarska-Schlattner M and Wallimann T (2006): Mitochondrial creatine kinase in human health and disease". Biochimica et Biophysica Acta; 1762 (2): 164-80.

Settimi L, Marcello I, Davanzo F et al., (2005): Update: Hydrogen Cyanamide--Related Illnesses - Italy, 2002--2004. Morbidity and Mortality Weekly Report; 54(16):405-8.

Shahidullah M, Duncan A, Peter D et al., (2002): Role of catalase in the smooth muscle relaxant actions of sodium azide and cyanamide.
European Journal of Pharmacology; 435(1):93-101.

Sheshadri H, Sudhir U, Kumar S et al., (2011): DORMEX $^{\circledR}$-hydrogen cyanamide poisoning. J Emerg Trauma Shock; 4(3): 435-37.

Xie G, Zheng X, Qi X et al., (2010): Metabolic evaluation of melamine-induced acute renal toxicity in rats. J. Proteome Res; 9 (1): 12533

Ware LB and Matthay MA (2005): Acute pulmonary edema. N Engl J Med; 353:2788-96.

Zimmemen HJ (1999): Hepatotoxicity the adverse effect of drugs and other chemicals.Medical789 $2^{\text {nd }}$ edition Lippincott Williams and Wilikins.pp:295-325.

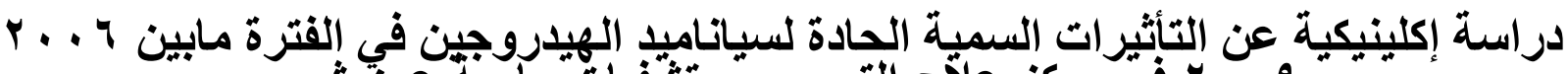

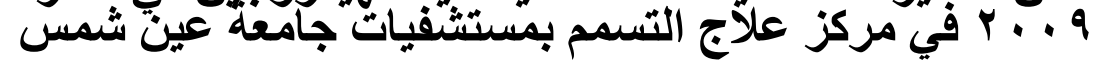

هاني أحمد جمال الدين و سوزان مصطفى محمود و منى القطب موسى و هبه محمد حلاوة و إيمان عبد الفتاح خليفة1

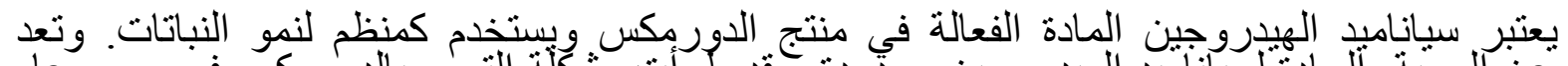

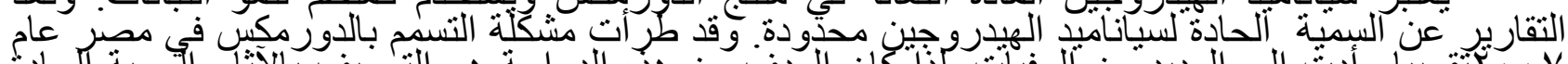

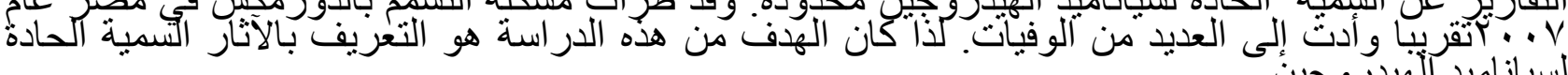

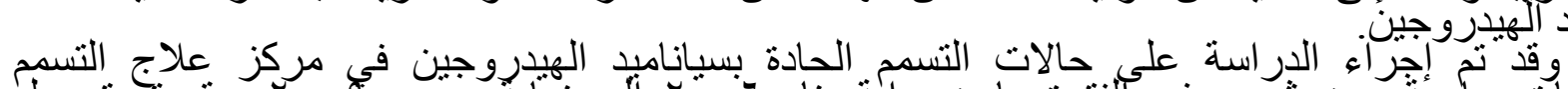

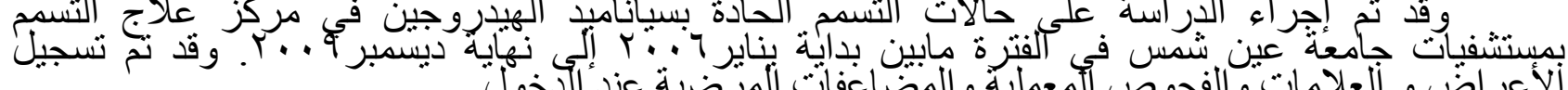

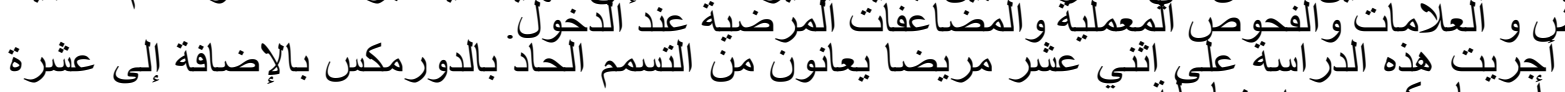

أثخاص أصحاء كمجمون عله ضابطة.

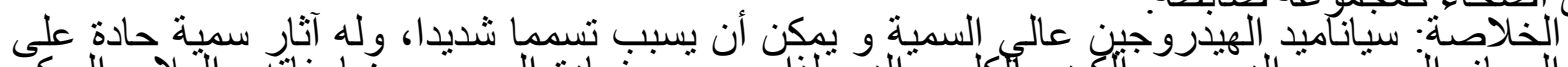

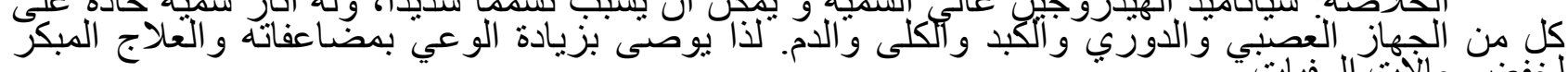
لخفض حالات الوفيات. الخبي 